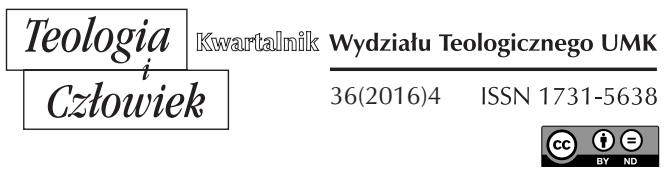

KS. TOMASZ DUTKIEWICZ*

TORUŃ

\title{
METAFIZYCZNA KONCEPCJA ZŁOŻEŃ WEWNĄTRZBYTOWYCH \\ I JEJ ROLA W WYKŁADZIE ANGELOLOGII \\ ŚW. TOMASZA Z AKWINU
}

DOI: http://dx.doi.org/10.12775/TiCz.2016.042

\section{WSTĘP}

Rozpoczynając wykład teologii zawarty w najbardziej znanym i zarazem najbardziej monumentalnym swoim dziele, jakim jest Suma teologiczna, św. Tomasz z Akwinu wychodzi od zagadnień natury metodologicznej, wskazując na potrzebę i wyjątkowość nauki, opartej na nadprzyrodzonym Objawieniu ${ }^{1}$. Chociaż jednak - co podkreśla - teologia nie

* Ks. Tomasz Dutkiewicz jest doktorem habilitowanym teologii oraz doktorem filozofii, wykładowcą na Wydziale Teologicznym UMK oraz w Wyższej Szkole Kultury Społecznej i Medialnej (tomasz.dutkiewicz@op.pl).

${ }^{1}$ Konieczność takiej nauki wynika - zdaniem Akwinaty - z faktu, że „prawdę o Bogu, zdobywaną wysiłkiem rozumu, nieliczni ludzie mogliby poznać po długim czasie szukania i to $\mathrm{z}$ domieszką wielu błędów, a przecież od znajomości tej prawdy zależy całkowicie zbawienie człowieka”. ST I, 1. 1. Wyjątkowy status metodologiczny teologii - jak wykazuje św. Tomasz - pozostaje natomiast w ścisłym związku z pewnością jej twierdzeń, jaką zawdzięcza ona autorytetowi objawiającego się Boga, a także z godnością przedmiotu, jakim się zajmuje. ST I, 1, 5. 
czerpie swoich zasad od innych nauk, to - celem lepszego uprzystępnienia podawanych prawd - czerpać może z osiągnięć filozofii ${ }^{2}$.

W sposób doniosły na znaczenie tej ostatniej zwrócił uwagę w wieku XIX papież Leon XIII, zaznaczając w encyklice Aeterni Patris, że posłużenie się wypracowanymi na gruncie realistycznej metafizyki pojęciami i zasadami jest niezbędne, by wiedza objawiona mogła być przedstawiona w formie spójnego i uporządkowanego wykładu³. Do myśli swojego wielkiego poprzednika, w czasach nam współczesnych, nawiązał Jan Paweł II, przedstawiając w encyklice Fides et ratio podwójną zasadę metodologiczną, określającą strukturę teologii jako nauki. Obejmuje ona kolejno: przyswojenie sobie przez człowieka treści objawionych (auditus fidei), następnie zaś ich wyjaśnienie, poprzez ukazanie ich logicznej spójności oraz przedstawienie ich w formie uporządkowanego systemu (intellectus fidei). Papież zwraca uwagę na fakt, że zarówno na pierwszym, jak i na drugim etapie uprawiania teologii, filozofia wnosi swój istotny wkład, bez którego uprawianie tej pierwszej byłoby niemożliwe ${ }^{4}$. Idąc tropem myśli zawartej w encyklice Aeterni Patris, której wydanie wsparło wielką odnowę myśli tomistycznej, Jan Paweł II ukazuje św. Tomasza z Akwinu jako „mistrza sztuki myślenia i wzór właściwego uprawiania teologii” ${ }^{5}$.

Doktor Anielski w sposób mistrzowski wykorzystuje, zarówno odziedziczone po poprzednikach, w szczególności po Arystotelesie, jak i samodzielnie wypracowane, instrumentarium filozoficzne tworzy pomnikowy wykład teologii, którego wartość trudno przecenić. W ramach poniższych rozważań chcemy zwrócić uwagę na jedno tylko - choć na terenie metafizyki niezwykle istotne - zagadnienie, jakim jest teoria złożeń bytowych, oraz na sposób, w jaki zostaje ono wykorzystane przez Akwinatę jako narzędzie racjonalizacji wiary w istnienie świata duchów czystych ${ }^{6}$.

2 ST I, 1. 5. Zagadnienie relacji „służebności” filozofii wobec teologii, której wyrazem jest, sięgające czasów patrystycznych, jej określenie mianem ancilla theologiae „służebnicy teologii”, szerzej podejmuje m.in. P. Moskal. Zob. Diakonia prawdy i „ancilla theologiae", w: Rozum otwarty na wiare, red. A. Maryniarczyk, Lublin 2000, s. 107-112.

3 Aeterni Patris, 24.

${ }^{4}$ Fides et ratio, 65-66.

5 Tamże, 43.

${ }^{6}$ Duchy te w sensie ścisłym nazywać można aniołami jedynie wówczas, kiedy pełnią funkcję posłańców, na co zwraca uwagę św. Augustyn, podkreślając fakt, że imię 


\section{KSZTAŁTOWANIE SIĘ METAFIZYCZNEJ KONCEPCJI ZŁOŻEŃ WEWNĄTRZBYTOWYCH}

Otaczająca człowieka rzeczywistość od czasów najdawniejszych stanowiła dla niego poważne wyzwanie poznawcze. Pierwszym narzędziem, jakim posłużył się on celem wyjaśniania i rozumienia świata był mit. Słabością mitologicznego tłumaczenia zjawisk był jednak niewątpliwie fakt, że pozyskiwane tą drogą odpowiedzi, choć zaspokajały naturalną ludzką potrzebę wiedzy, to jednak w sposób oczywisty rozmijały się z rzeczywistością. O narodzinach filozofii zadecydowało dążenie do sformułowania odpowiedzi prawdziwych, co oznaczać musiało w praktyce konieczność przezwyciężenia mitu, posłużenie się rozumem w miejsce wyobraźni oraz wskazanie rzeczywistych przyczyn, w oparciu o które zrozumieć można by zachodzące w świecie zjawiska. W szczególności chodzić miało o wyjaśnienie faktu różnorodności bytów oraz obserwowanych w przyrodzie zmian.

\subsection{MONISTYCZNA INTERPRETACJA RZECZYWISTOŚCl - POZORNA ZŁOŻONOŚĆ BYTU, WYNIKIEM NAGROMADZENIA MATERIALNYCH PRAELEMENTÓW}

Pierwsza, filozoficzna próba wyjaśnienia rzeczywistości pozostaje $\mathrm{w}$ ścisłym związku $\mathrm{z}$ doniosłym pytaniem, sformułowanym $\mathrm{w}$ środowisku szkoły jońskiej, które przeszło do historii jako tzw. pytanie o arche. Sam grecki termin arche posiada wiele znaczeń i może być tłumaczony jako „początek”, „prazasada”, „praprzyczyna”. Dość wspomnieć, że tego właśnie terminu użyje wiele wieków później św. Jan, pisząc w prologu swojej Ewangelii o Słowie, które było „na początku” (J 1,1). Póki co jednak, Tales

anioł nie oznacza natury, lecz zadanie. Enarratio in Psalmos, 103, 1, 15. W podobny sposób wypowiada się również św. Grzegorz Wielki, w tekście znanym z Liturgii Godzin ze święta Świętych Archaniołów. Homilia 34, 8. Św. Tomasz w Sumie teologicznej posługuje się terminem „anioł” w sensie szerszym, używając go w kontekście, w jakim w innych jego pismach pojawia się termin „substancja oddzielona” (od materii). Zachowując świadomość co do zasadności przytoczonej wcześniej uwagi, ze względów praktycznych, używać będziemy terminu „anioł” w znaczeniu szerszym, jako stworzoną przez Boga istotę niecielesną. 
z Miletu i jego następcy poszukując prazasady świata, rozumieją arche w sposób jednoznacznie materialny ${ }^{7}$. Daje temu wyraz Arystoteles, który rozpoczynając swoje dociekania zawarte w Metafizyce od krytycznego przeglądu wcześniejszych stanowisk, stwierdza, że „spośród pierwszych filozofów większość przyjmowała zasady w formie materii jako jedyne zasady wszystkich rzeczy"s.

Różnorodność świata w świetle przedstawionej w ten sposób interpretacji pozostaje zatem wyłącznie czymś pozornym, wszelkie zaś konkretne przedmioty potraktowane zostają jako zwielokrotnienie tego samego elementu (lub elementów) ${ }^{9}$. Ich jednostkowość oraz indywidualność posiada charakter czysto zjawiskowy i pojawia się jedynie jako rezultat składania pracząstek. Poszczególne byty nie posiadają zatem swoich odrębnych natur, istnieje jedynie ogólna i powszechna natura wszystkiego, której osnową jest ten lub inny pierwiastek (pierwiastki) stanowiący(e) arche wszechrzeczy ${ }^{10}$.

Podobnie, obserwowane $\mathrm{w}$ świecie zmiany, również powstawanie i ginięcie rzeczy, przedstawione zostają jako niezbyt skomplikowany proces łączenia się i rozkładania pracząstek. Jedyne metafizyczne złożenie, o jakim mówić można w tym kontekście, to czasowe ich zgromadzenie się $\mathrm{w}$ formie agregatu, który nie może być uznany za rzeczywisty byt, gdyż bytowość jako taka przypisana może być w sposób uprawniony jedynie temu co wieczne, niezłożone i niezmienne, a więc stanowiącej osnowę wszechrzeczy prazasadzie ${ }^{11}$.

${ }^{7}$ Chociaż jako pierwszy samego terminu arche użył najprawdopodobniej Anaksymander, to jednak już wskazanie przez Talesa z Miletu na wodę jako na pratworzywo rzeczywistości, pozwala wnioskować, że myślicielowi temu bliski był problem badawczy wyrażony we wspomnianym pytaniu o arche. Zob. G. Reale, Historia filozofii starożytnej, tłum. I. Zieliński, t. I, Lublin 1993, s. 76.

${ }^{8}$ Metafizyka, 983 b, tłum. K. Leśniak, Warszawa 1984.

9 „Nie wszyscy - jak zauważa Arystoteles - zgadzają się co do ilości i natury tych zasad”. Tamże. Jako arche rzeczywistości, obok wody wskazywano np. powietrze (Anaksymenes), ogień (Heraklit), ale również żywioły - wodę, ogień, powietrze i ziemię (Empedokles).
10 A. Maryniarczyk, Zeszyty z metafizyki, t. I, Lublin 1998, s. 49-50.
11 Tamże, s. 50-52. 


\subsection{DUALISTYCZNA INTERPRETACJA RZECZYWISTOŚCI - IDEALNA PROSTOTA PRAWDZIWEGO BYTU}

Myślicielem, którego niewątpliwą zasługą pozostaje przełamanie pierwotnego materializmu monistów oraz odkrycie rzeczywistości duchowej jest Platon. Tworzy on jednak zarazem oryginalną interpretację rzeczywistości, w której dwa światy - duchowy i materialny - zostają sobie w radykalny sposób przeciwstawione jako sfera bytu i niebytu, dobra i zła, co swego szczególnego dramatyzmu nabiera w wyrastającej na gruncie tej interpretacji antropologii. Człowiek to dusza, która przebywając w ciele jak w grobie, zapomniała o swoim boskim pochodzeniu i żyje zniewolona, co w obrazowy sposób przedstawia platoński mit jaskini i uwięzionych w niej „kajdaniarzy osobliwych”" ${ }^{2}$.

U podstaw platońskiej metafizyki legło odziedziczone po twórcy szkoły eleackiej, Parmenidesie, przekonanie, że prawdziwy byt jest wieczny i niezmienny. Stąd wniosek, że świat poznawany dzięki zmysłom, który jawi się jako swoiste teatrum dokonujących się nieustannie przemian i procesów, jest światem nierzeczywistym, pozornym. Dlatego też twierdzenie, że jedyną władzą poznawczą, pozwalającą człowiekowi przedrzeć się przez łudzącą go grę cieni i dotrzeć do prawdziwego bytu, jest rozum. To dzięki rozumowi zdolni jesteśmy oddać się kontemplacji idei - bytów nie posiadających postaci, ogólnych, niezmiennych i wiecznych ${ }^{13}$.

Pomysł dotyczący idei Platon zaczerpnął od swojego mistrza, Sokratesa, który choć sam metafizyką się nie zajmował, na potrzeby uprawianej przez siebie refleksji etycznej stworzył teorię definiowania pojęć.

12 Państwo, 514 a, tłum. W. Witwicki, Warszawa 2003. Antropologia platońska sięga swoimi korzeniami czasów przedfilozoficznych i stanowi recepcję na gruncie filozofii treści zawartych w starożytnych wierzeniach orfickich. Zob. więcej na ten temat: G. Reale, Historia filozofii starożytnej, tłum. I. Zieliński, t. I, Lublin 1994, s. 50-51.

${ }^{13}$ Parmenides jest prekursorem skrajnego racjonalizmu teoriopoznawczego, który kwestionując wartość poznania zmysłowego za punkt wyjścia obiera treści świadomości. W platonizmie będą nimi idee istniejące obiektywnie poza światem materialnym, które ludzka dusza miała możliwość kontemplować, zanim połączyła się z ciałem - stąd koncepcja poznania anamnetycznego, będącego w swej istocie przypominaniem. W tradycji postkartezjańskiej punkt wyjścia refleksji filozoficznej stanowić będą idee obecne w ludzkim umyśle. 
W procesie definiowania Sokratesowi chodziło o to, by w zbliżonych do siebie ludzkich zachowaniach wskazać to, co jest im wspólne i uchwycić w ten sposób istotę rzeczy (np. męstwa, które w różny sposób manifestować się może, zależnie od warunków) ${ }^{14}$. W podobny sposób definiuje się również poszczególne pojęcia ogólne, odnoszące się do różnorodnych zbiorów desygnatów. Z punktu widzenia realistycznej interpretacji rzeczywistości, pojęcia te pozostają jedynie wytworem abstrakcyjnego myślenia i - jako takie - istnieją w ludzkim intelekcie, po stronie rzeczywistości odpowiadają im natomiast zbiory cech wspólnych dla danej klasy bytów, istniejących w tych właśnie bytach. Innego zdania jest jednak Platon, który uprzedmiotawiając sensy pojęć ogólnych, przypisuje im istnienie ogólnych desygnatów, które nazywa ideami. To one stanowią dziedzinę prawdziwego bytu, spełniającego wymogi postawione przez eleatów - niezłożonego, niezmiennego, niezniszczalnego, wiecznego ${ }^{15}$.

\subsection{REALISTYCZNA INTERPRETACJA RZECZYWISTOŚCI ARYSTOTELESA - BYT JAKO KONKRET ZŁOŻONY Z MATERII I FORMY}

Arystoteles, poddając krytyce zarówno materializm najstarszych filozofów, jak i stworzoną przez Platona teorię idei, postuluje, by w wyjaśnianiu rzeczywistości wyjść od obrazu świata takiego, jakim przedstawiają go ludzkie zmysły. Realny świat, w przeciwieństwie do jego obrazu skonstruowanego na drodze logicznych analiz (co Stagiryta zarzuca swojemu mistrzowi), przedstawia się jako złożony $\mathrm{z}$ wielości odrębnych substancji, które różnią się pomiędzy sobą w sposób rzeczywisty, nie zaś jedynie zjawiskowy. Podobnie, za rzeczywiste uznaje filozof ich powstawanie i ginięcie oraz procesy przemian, którym podlegają.

Celem wyjaśnienia faktycznej, nie zaś wyłącznie pozornej różnorodności i zmienności bytów, Arystoteles odwołuje się do koncepcji

${ }^{14}$ Szerzej zagadnienie to przedstawia R. Legutko. Zob. Sokrates, Poznań 2013, s. $291 \mathrm{nn}$.

15 Zapoczątkowany w starożytności spór o to, co po stronie rzeczywistości odpowiada pojęciom ogólnym, szczególnej intensywności nabierze w średniowieczu jako tzw. spór o uniwersalia. Zob. więcej na ten temat: A.B. Stępień, J. Herbut, Uniwersalia, w: Leksykon filozofii klasycznej, red. J. Herbut, Lublin 1997, s. 526-527. 
zakładającej wewnętrzną ich złożoność, zwanej hylemorfizmem. Zgodnie $\mathrm{z}$ tą koncepcją, w strukturze każdego bytu, wyróżnić można dwa elementy: materię (gr. hyle), stanowiącą składnik bierny, podlegający kształtowaniu, oraz formę (gr. morfe), pełniącą rolę czynnika kształtującego. Dzięki temu złożeniu byt posiada swoją jednostkowość i odrębność, może zmieniać się zachowując swoją tożsamość, a także być przedmiotem poznania, zarówno zmysłowego, jak i intelektualnego ${ }^{16}$.

Materia i forma łączą się ze sobą jako pewna potencjalność (możność) oraz akt, kształtujący ją i decydujący o powstaniu konkretnej rzeczy. Podobnie również zmiany, jakim rzecz ta podlega już istniejąc, wyjaśnić można jako przejście (pod pewnym względem) z możności do aktu, ze stanu potencjalnego do stanu aktualnego, zrealizowanego ${ }^{17}$.

\subsection{REWOLUCJA TOMISTYCZNA - EGZYSTENCJALNA KONCEPCJA BYTU JAKO KONKRETU ZŁOŻONEGO Z ISTOTY I ISTNIENIA}

Arystotelesowskie ujęcie bytu jako realnie istniejącej, wewnętrznie złożonej, jednostkowej substancji, posiadało jednak swoje ograniczenia. Były one wynikiem przyjmowanego a priori, szeroko rozpowszechnionego w greckim świecie przekonania, w myśl którego świat jako całość istnieje odwiecznie $^{18}$. W przypadku Stagiryty wyrażało się ono w uznaniu wiecz-

${ }^{16}$ Arystoteles odwołuje się do przykładu spiżowej kuli, która nie dlatego jest kulą, że powstała ze spiżu, ale dzięki stanowiącej jej formę kulistości, w odpowiedni sposób kształtującej materię: kula - jak pisze - „utworzona została ze spiżu i z kulistego kształtu, czyli w ten sposób, że się ten materiał ujęło w taką właśnie formę i w wyniku tego powstała kula spiżowa”. Metafizyka, 1033 a-b.

17 Rzeźba Hermesa - wyjaśnia Stagiryta - jest potencjalnie w drzewie, tak jak połowa $\mathrm{w}$ całości, ponieważ może być z niej wydzielona; człowieka, który nigdy nie studiował, nazwać możemy potencjalnie uczonym, jeśli tylko zdolny jest do studiowania. Stan przeciwny, tzn. stan, w którym możność zostaje zrealizowana, Arystoteles nazywa aktualnym. Metafizyka, 1048 a.

${ }^{18} \mathrm{O}$ tym, jak silne było to przeświadczenie również w starożytności chrześcijańskiej, świadczyć może sposób, w jaki liczni spośród Ojców Kościoła skłonni byli interpretować biblijne teksty, dotyczące stworzenia świata. Akt stwórczy opisywany był przez nich niejednokrotnie jako kształtowanie bezładnej materii, samego zaś Stwórcę określali oni mianem „demiurga” (gr. demiurgos). W podobny sposób przedstawia Boga nawet powstała około 389 roku Constitutio Apostolica. Więcej 
nego istnienia substratu, jakim była materia pierwsza, w obrębie której zmieniać się mogły jedynie formy ją kształtujące. Skutkiem przyjęcia takiego założenia na terenie metafizyki, stała się tzw. esencjalna koncepcja bytu, zgodnie z którą o jego istnieniu decydować miała forma (późniejsze lac. essentia).

Zrywając z obciążonym starożytną kosmologią obrazem świata, św. Tomasz formułuje na nowo problem badawczy, z jakim zmierzyć się musi metafizyka. Ma nim być wskazanie na ostateczną przyczynę istnienia wszechrzeczy, nie zaś tylko na przyczynę zmian zachodzących w istniejącym już świecie. Postawienie w nowy sposób pytania, mającego wyznaczyć kierunek metafizycznych poszukiwań, okaże się rewolucyjne i zaowocuje pogłębionym rozumieniem bytu, sformułowaniem filozoficznej teorii creatio ex nihilo, a także da antropologiczne podstawy do uznania nieśmiertelności ludzkiej duszy ${ }^{19}$.

Przyjęcie złożenia bytu $\mathrm{z}$ materii i formy nie jest w stanie - zdaniem Akwinaty - wyjaśnić ostatecznie istnienia substancji, wyjaśnia ono bowiem, co najwyżej, fakt ukształtowania istniejącej już materii do bycia tym oto konkretnym bytem. By odpowiedzieć na pytanie o rację istnienia bytu, wskazać trzeba w jego strukturze na złożenie głębsze, ontologicznie wcześniejsze aniżeli złożenie hylemorficzne, złożenie $\mathrm{z}$ istoty oraz - proporcjonalnego do niej - istnienia. W ten sposób św. Tomasz tworzy nową, egzystencjalną koncepcję bytu, niejako podwójnie złożonego: $\mathrm{z}$ - mieszczących się w obrębie istoty - materii i formy; oraz złączonego $\mathrm{z}$ tą istotą aktu istnienia. Podobnie jak forma wobec materii, tak akt ten wobec istoty występuje $\mathrm{w}$ relacji aktu do możności i to właśnie on, nie zaś forma, stanowi wyjaśnienie istnienia bytu ${ }^{20}$.

na ten temat pisze A. Maryniarczyk. Zob. Zeszyty z metafizyki, t. III, Lublin 1999, s. $43 \mathrm{nn}$.

19 Przyjęcie jako swoistego poznawczego a priori faktu odwiecznego istnienia świata, stanowiło źródło istotnych ograniczeń arystotelesowskiej metafizyki, wśród których wymienić można esencjalizm w koncepcji bytu, redukcję roli Bytu Absolutnego w stosunku do świata do funkcji zapoczątkowania zachodzących w nim zmian (Nieporuszony Poruszyciel) oraz - $\mathrm{w}$ antropologii - negację jednostkowej nieśmiertelności.

${ }^{20}$ Jest rzeczą znamienną, że jedno z najdoskonalszych - zdaniem wybitnego tomisty, E. Gilsona - sformułowań tłumaczących to zagadnienie, Akwinata zawarł w dziele z zakresu angelologii: „W substancji złożonej z materii i formy znajduje się porządek 
2. STRUKTURA BYTOWA SUBSTANCJI ODDZIELONYCH OD MATERII KONTROWERSJE I ICH ROZWIAZZANIE NA GRUNCIE ANGELOLOGIl ŚW. TOMASZA Z AKWINU

Wspominaliśmy już wyżej o trudnościach, z jakimi do umysłowości chrześcijańskich myślicieli torować sobie musiała prawda o stworzeniu świata, rozumianym - jak ujmie to w swojej Summa contra gentiles św. Tomasz - jako „wytworzenie bytu, kiedy uprzednio żaden byt nie istniał" 21 . Na przeszkodzie stawało jej uporczywie odziedziczone po starożytnych myślicielach przekonanie o wieczności świata, powodując, że wbrew, jednoznacznym w tej kwestii, tekstom biblijnym, skłonni byli oni interpretować dzieło stworzenia na sposób demiurgicznego działania na istniejącym już wcześniej materiale. Podobnych trudności nastręczało wielu autorom uznanie czysto duchowej natury aniołów. Prostota bytu, jego niezłożenie z materii i formy, kojarzyły się nader mocno z byciem czystym aktem, bez domieszki możności, co wydawało się być atrybutem samego tylko Boga.

\subsection{DLACZEGO „DOKTOR ANIELSKI"?}

W tradycji filozoficzno-teologicznej mamy do czynienia z całym szeregiem tytułów „doktorskich”, które w połączeniu z różnymi określeniami zwykło się przypisywać wybranym autorom, akcentując w ten sposób określone przymioty ich osobowości, czy też wyjątkowy charakter ich dzieł. W ten to sposób św. Augustyna nazwano „Doktorem Łaski” - Doctor Gratiae, Aleksandra z Halles „Doktorem Niezłomnym” - Doctor Irrefragabillis, św. Bonawenturę „Doktorem Seraficznym” - Doctor Seraphicus, Jana Dunsa Szkota „Doktorem Najdociekliwszym” - Doctor Subtilissimus.

podwójny: jeden - samej materii w stosunku do jej formy; drugi - rzeczy już złożonej w stosunku do istnienia, w którym uczestniczy. W rzeczywistości istnienie rzeczy nie stanowi ani jej formy, ani jej materii, lecz aliquid, które dochodzi do rzeczy przez jej formę". De substantis separatis, 6. Cyt. za: E. Gilson, Byt i istota, tłum. D. Eska, J. Nowak, Warszawa 2006, s. 80-81.

${ }^{21}$ CG, II, 21. 
Św. Tomaszowi z Akwinu, obok tytułu „Doktora Anielskiego” Doctor Angelicus, nadano także inne, jak Doctor Communis (tytułu tego użył papież Jan XXII, kanonizując Tomasza w 1323 roku), czy „Doktora Powszechnego" - Doctor Universalis (tytułem tym posłużył się w swej bulli Mirabilis Deus papież Pius V, ogłaszając w 1567 roku św. Tomasza Doktorem Kościoła ${ }^{22}$.

Przypisanie Akwinacie tytułu „Doktora Anielskiego” bywa zazwyczaj łączone z faktem opracowania przezeń w sposób systematyczny szeregu kwestii z zakresu angelologii, zarówno w obu Sumach - teologicznej (Summa theologiae) i filozoficznej (Summa contra gentiles), jak również w odrębnych traktatach, z których na szczególną uwagę zasługują De substantis separatis - O substancjach czystych oraz kwestie dyskutowane De spiritualibus creaturis - O stworzeniach duchowych ${ }^{23}$.

Interesujące wydaje się jednak spostrzeżenie, jakie czyni w tym kontekście S. Swieżawski, który - nie kwestionując powyższego, jak również innych, utrwalonych w tradycji, sposobów wyjaśniania genezy tego tytułu - wskazuje na niebywałą gorliwość, z jaką św. Tomasz podejmuje problematykę związaną z istnieniem duchów czystych oraz dowodzi ich niematerialności. Swieżawski podkreśla ponadto fakt, że w tradycyjnej filozofii i teologii niekiedy dość tendencyjnie zacierano różnicę pomiędzy człowiekiem a aniołem. Stąd właśnie - jego zdaniem - owa wyjątkowa determinacja ze strony Akwinaty, by wykazać zasadniczą różnicę, zachodzącą pomiędzy naturą aniołów i naturą ludzką, stąd również - ostatecznie - jego zaszczytny tytuł „Doktora Anielskiego”24.

${ }^{22}$ M. Markowski, Doktor, w: Encyklopedia Katolicka, red. R. Łukaszyk, L. Bieńkowski, F. Gryglewicz, Lublin 1989, t. IV, kol. 34; W. Danielski, Doktor Kościoła, tamże, kol. 34-35.

${ }^{23}$ Do tytułu „Doktora Anielskiego” w czasach nam współczesnych nawiązał w encyklice Fides et ratio papież Jan Paweł II. Fides et ratio, 43-44.

${ }^{24}$ S. Swieżawski, Święty Tomasz na nowo odczytany, Kraków 1983, s. 110-111. Obok przedstawionych powyżej interpretacji „anielskiego” tytułu Akwinaty, autor ten przywołuje również dwie inne: pierwszą, nawiązującą do heroicznej czystości, jaką miał się wykazać Tomasz w obliczu prób, na jakie wystawiany był przez swoją rodzinę, przeciwną jego woli wstąpienia do zakonu dominikanów; oraz drugą, nawiązującą do żywej w tym zakonie legendy o aniołach posilających św. Dominika i jego towarzyszy. 
Jak można przypuszczać, źródeł wspomnianych tendencji, zmierzających do zacierania różnicy pomiędzy światem ludzi i światem duchów czystych, doszukiwać się należy w oddziałującym silnie na myśl chrześcijańską platonizmie wraz z jego spirytualizmem, wyrażającym się w redukcji ludzkiej natury do jej wymiaru duchowego. Tego rodzaju podejście już w starożytności chrześcijańskiej fascynowało wielu myślicieli, którzy w filozofii podkreślającej moment transcendencji człowieka, jego pozaziemskie pochodzenie oraz nieśmiertelność ludzkiej duszy, skłonni byli upatrywać naturalnego „sojusznika” prawdy objawionej ${ }^{25}$. Św. Tomasz jednak dobrze rozumie nieprzystawalność dualistycznej metafizyki i antropologii do - wynikającej z Objawienia - wizji świata oraz człowieka. Dlatego też dąży on do przełamania redukcjonistycznego spirytualizmu na rzecz całościowego ujęcia ludzkiej natury jako duchowo-cielesnego compositum. W tym ujęciu nawet oddzielona od swego ciała ludzka dusza pozostaje czymś nieporównywalnym i w zasadniczy sposób różnym od bytów czysto duchowych ${ }^{26}$.

\subsection{SPÓR O HYLEMORFICZNA ZŁOŻONOŚĆ ANIOŁÓW}

W świetle wcześniejszych stwierdzeń, zrozumiały wydaje się fakt, że kwestią zasadniczą $\mathrm{w}$ angelologii św. Tomasza z Akwinu pozostaje zagadnienie niematerialności aniołów. Pragnąc możliwie najdobitniej tę

${ }^{25}$ Perypetie związane z próbą asymilacji platonizmu na gruncie chrześcijańskim szerzej opisuje m.in. E. Gilson na przykładzie trudności, na jakie napotyka najwybitniejszy przedstawiciel patrystyki łacińskiej, św. Augustyn, który - jak stwierdza francuski tomista -był „niedościgłym wyrazicielem mądrości chrześcijańskiej, ale nie posiadał nigdy filozofii dla swej teologii”. E. Gilson, Bóg $i$ ateizm, tłum. M. Kochanowska, P. Murzański, Kraków 1996, s. 51-59.

${ }^{26}$ Zagadnieniu temu Akwinata poświęca osobny rozdział w swojej Sumie filozoficznej. CG, II, 94. Wcześniej także, wykazując konieczność uznania istnienia substancji czysto duchowych, pisze: „tak jak ciało udoskonalone przez duszę obdarzoną intelektem jest najwyższe w rodzaju ciał, tak dusza umysłowa, która łączy się z ciałem, musi być najniższa w rodzaju substancji umysłowych". Tamże, II, 91. Warto również przywołać w tym kontekście zagadnienie tzw. commensuratio. Zob. więcej na ten temat: S. Swieżawski, Centralne zagadnienie tomistycznej nauki o duszy (Commensuratio animae ad hoc corpus), „Przegląd Filozoficzny” 44 (1948) 1-3, s. 131-191. 
niematerialność wyrazić, Akwinata ucieka się do szeregu określeń, takich jak substantiae separatae - „substancje oddzielone”, substantiae abstractae - „substancje oderwane” (od materii), substantiae immateriales - „substancje niematerialne”, substantiae purae - „substancje czyste”27.

Jednoznaczne stanowisko, jakie Akwinata zajmuje w tej kwestii jest niezwykle ważnym głosem w sporze, który rozpalał umysły Średniowiecza, a który koncentrował się wokół zagadnienia hylemorficznej złożoności aniołów. Temperatura tego sporu staje się zrozumiałą wówczas, gdy uświadamiamy sobie fakt, że - w myśl szeroko przyjmowanej opinii - każdy byt, z wyjątkiem samego tylko Absolutu, zawiera w swojej strukturze dwa czynniki - formę oraz materię - pojęte, w duchu arystotelesowskim, jako akt i możność. Zgodnie z powyższym założeniem, uznanie istnienia wielości pozbawionych materii, duchowych substancji, musiałoby oznaczać tym samym przyznanie im prerogatyw boskich oraz - co za tym idzie - negację podstawowej w religiach objawionych prawdy, dotyczącej jedyności Boga.

Dlatego też, według niektórych myślicieli, nieuniknionym pozostaje uznanie faktu hylemorficznego złożenia w strukturze bytowej aniołów, co w konsekwencji oznaczać musi opowiedzenie się za przekonaniem, w myśl którego posiadają one jakiś rodzaj materii. Akwinata w różnych miejscach przywołuje opinie rozlicznych autorytetów, zdające się przemawiać za słusznością takiego właśnie stanowiska.

W swej Sumie teologicznej, stawiając pytanie o bezcielesność aniołów, w ramach, charakterystycznego dla struktury dzieła, videtur quod - „wydaje się, że”, przytacza opinię Jana Damasceńskiego, w myśl której anioł uchodzi za niematerialnego jedynie w zestawieniu z ludźmi, w zestawieniu $\mathrm{z}$ Bogiem pozostaje natomiast cielesny i materialny ${ }^{28}$. Przywołuje także stwierdzenie św. Ambrożego, zgodnie z którym wszelkie

${ }^{27}$ J. Salij, który dzieło św. Tomasza przetłumaczył oraz opatrzył wstępem, stwierdza, że „W całym dziedzictwie chrześcijańskim trudno znaleźć drugie dzieło, w którym z równą wnikliwością ujęto by problem stworzeń bytowo doskonalszych od człowieka", przytoczone natomiast ich określenia, którymi posługuje się Akwinata wskazują na fakt, że „chodzi tu o samodzielne, niezależne od materii formy”. Św. Tomasz z Akwinu, Dzieła wybrane, red. J. Salij, Kęty 1999, s. 504-505.

${ }^{28}$ ST I, 50, 1, 1. Tę samą opinię Jana Damasceńskiego św. Tomasz cytuje również w De substantis separatis, 19. 
stworzenie posiada swoje granice, co jest cechą charakterystyczną bytów materialnych ${ }^{29}$.

W De substantis separatis cytuje natomiast Orygenesa, który w dziele Peri archon - O zasadach, stwierdza w sposób kategoryczny, że istnienie bez substancji materialnej oraz bez jakiejkolwiek domieszki czegokolwiek cielesnego, właściwe jest jedynie naturze samego $\operatorname{Boga}^{30}$. Osobny rozdział traktatu św. Tomasz poświęca przedstawieniu poglądów średniowiecznego myśliciela, Awicebrona, który na rzecz hylemorficznego złożenia aniołów formułuje cały szereg argumentów ${ }^{31}$.

W De spiritualibus creaturis, obok wspomnianego już poglądu Orygenesa, znajdujemy nawiązanie do dekretu papieża Paschasiusa, w którym znalazło się wyraźne sformułowanie, w myśl którego spiritualia sine corporibus subsistere non posunt - „substancje duchowe pozbawione ciał istnieć nie mogą"32. Akwinata przytacza tam także tekst św. Bernarda, w którym autor ten, w sposób równie kategoryczny stwierdza, że non spiritus creatur sine corpore invenitur - „nie sposób znaleźć stworzonej substancji duchowej pozbawionej ciała” ${ }^{33}$.

Obok argumentacji ex auctoritate na rzecz złożenia aniołów z materii i formy św. Tomasz przywołuje również możliwe rozumowania na

29 ST I, 50, 1, 3.

${ }^{30}$ Powyższy pogląd Orygenesa Akwinata przytacza w De substantis separatis, 19. Ten sam cytat pojawia się również w De spiritualibus creaturis, 5, 1.

31 Tomasz przytacza w De substantis separatis, w rozdziale piątym, argumentację jaką Awicebron zawarł w swoim dziele Źródło życia. Dzieło to, przedstawiające jedną $\mathrm{z}$ najbardziej konsekwentnych koncepcji emanacji, powstałych $\mathrm{w}$ średniowieczu, napisane zostało $\mathrm{w}$ języku arabskim. Akwinata korzysta z jego łacińskiego przekładu zatytułowanego Fons vitae, którego dokonali Dominik Gundissalvi oraz Jan Hiszpan. Sam Awicebron jako pierwszy na Zachodzie (XI w.) propagator neoplatonizmu, zwany Żydowskim Platonem, tworzy swoistą kompilację myśli żydowskiej oraz poglądów Arystotelesa i Platona. Jest wyrazicielem tzw. hylemorfizmu powszechnego, w myśl którego wszystkie substancje poza Bogiem, zarówno cielesne, jak i duchowe, posiadają wspólną, niecielesną materię. M. Kurdziałek, Awicebron, w: Powszechna Encyklopedia Filozofii, red. A. Maryniarczyk, t. I, Lublin 2000, s. 440. Dalszą część wywodów św. Tomasza zajmuje krytyka zarzutów, podniesionych przez Awicebrona przeciw niematerialności aniołów. De substantis separatis, 6.

${ }_{32}$ De spiritualibus creaturis, 5, 2.

33 Tamże, 5, 3. 
rzecz takiego stanowiska, nawiązujące do arystotelesowskiego hylemorfizmu oraz teorii aktu i możności. Oto kilka - najważniejszych, jak się wydaje - spośród przytoczonych przezeń zarzutów, jakie podnieść można przeciwko niematerialności duchów czystych ${ }^{34}$.

Po pierwsze: skoro zasada ruchu i zmienności tkwi w materii, to w każdej rzeczy, w znaczeniu arystotelesowskim poruszającej się, tzn. podlegającej przemianom, musi znajdować się materia, będąca podłożem tych zmian. Substancje duchowe zwane aniołami podlegają zmianom i ruchowi, gdyż jedynie Bóg pozostaje z natury niezmienny. Stąd też we wszelkich bytach stworzonych, również tych duchowych musi znajdować się materia ${ }^{35}$.

Po drugie: każdy działający byt działa dzięki swej formie, która jest aktem; może natomiast doznawać działania, dzięki możności, jaką jest materia. Duchowe substancje stworzone działają w ten sposób, że konkretny anioł oświecany jest przez anioła bezpośrednio od siebie wyższego, oświeca zaś anioła bezpośrednio od siebie niższego. Każdy zatem anioł zarówno działa, jak i doznaje działania, stąd też każdy anioł składać się musi z formy i materii ${ }^{36}$.

Po trzecie: tym, co ogranicza formę i czyni ją skończoną, jest materia. Forma pozbawiona materii jest zatem formą nieskończoną. Skoro jednak wszelkie stworzenia istnieją jako skończone, również anioł musi posiadać materię ${ }^{37}$.

Po czwarte: wszystko, co istnieje realnie, istnieje jako złożone $\mathrm{z}$ materii i formy lub też jest czystym aktem. Tym ostatnim jest jednak jedynie Bóg. Zatem duchowe substancje stworzone jeśli nie są bogami, istnieć muszą jako złożone $\mathrm{z}$ materii i formy ${ }^{38}$.

Skoro jednak zarówno prawda o jedyności Boga, jak i prawda o niematerialnej naturze aniołów znajdują swoje jednoznaczne potwierdzenie w tekstach objawionych, zadaniem, w obliczu którego stanął Akwinata, idąc za wskazaniem zasady fides querens intellectum, było znalezienie

\footnotetext{
34 Zob. E. Gilson, Tomizm, tłum. J. Rybałt, Warszawa 1998, s. 195.

${ }^{35}$ De spiritualibus creaturis, $1,3$.

36 Tamże, 1, 16.

37 ST I, 50, 2.

${ }^{38}$ De spiritualibus creaturis, 1, 17; ST I, 50, 2.
} 
odpowiedzi na pytanie o strukturę bytową substancji czysto duchowych, nie będących jednocześnie bogami ${ }^{39}$.

\subsection{ROZWIAZZANIE TRUDNOŚCI NA GRUNCIE KONCEPCJI BYTU ZłOŻONEGO Z ISTOTY I ISTNIENIA}

To, co wydawało się niemożliwością na gruncie arystotelesowskiego hylemorfizmu, o czym świadczył opisany wyżej swoisty impas poznawczy, stało się możliwe dzięki odwołaniu się do pogłębionej koncepcji bytu, wypracowanej przez św. Tomasza.

Wspomniana już wcześniej w jej szczegółach, egzystencjalna koncepcja bytu, ukazuje byt jako złożony nie tylko z materii i formy, ale przede wszystkim zawierający w sobie dwa nie dające się sprowadzić do siebie nawzajem komponenty: istotę oraz - proporcjonalne do niej - istnienie. Wyjątkiem pozostaje w tym względzie wyłącznie Bóg, który bytuje jako całkowicie niezłożony. O nim jedynie orzekać możemy w stopniu absolutnym: prostotę (brak jakichkolwiek złożeń bytowych), niezmienność (bycie czystym aktem) oraz - co stanowi metafizyczną podstawę wszelkich innych Jego przymiotów - samo istnienie.

W myśl egzystencjalnej koncepcji bytu, zasadnicza linia demarkacyjna, dzieląca poszczególne jestestwa, nie będzie zatem przebiegać pomiędzy tym, co duchowe i tym, co materialne. Zostaje ona wytyczona pomiędzy Tym „który jest” - będąc Samym Istnieniem (ipsum esse) - oraz tym, co stworzone, co istnieje jedynie na kredyt, otrzymując istnienie udzielane za pośrednictwem przyczyn znajdujących się na zewnątrz bytu. Pozostaje zatem prawdziwym stwierdzenie, że jedynie Bóg sam jeden jest czystym aktem, tyle, że do Jego boskich prerogatyw należy nie tylko bycie nim w porządku złożenia z możności-materii oraz aktu-formy. To złożenie nie występuje bowiem także w czystych substancjach duchowych, stworzonych przez Niego oraz od Niego zależnych w swoim istnieniu.

${ }^{39}$ W sposób syntetyczny kwestię tę ujmuje Gilson, pisząc: „Kiedy się zastanowimy, co było najistotniejsze w całym tym średniowiecznym sporze o hylemorficzną złożoność aniołów, dojdziemy do wniosku, że w gruncie rzeczy zmierzał on do rozwiązania jednego tylko problemu: jak należy pojmować proste substancje duchowe nie będące bogami?", Tomizm, s. 198. 
Bycie Bogiem - Bytem Absolutnym - wyraża się w czymś więcej: byciu czystym aktem istnienia, w którym nieobecne jest złożenie z możności-istoty oraz tego właśnie aktu.

W ten sposób na gruncie egzystencjalnej koncepcji bytu rozwiązana zostaje pozorna aporia pomiędzy uznaniem jedyności Boga oraz niematerialności duchów czystych. Być czystym aktem w sensie bycia absolutem nie oznacza jedynie być pozbawioną materii formą, ale być czystym istnieniem. Aniołowie - jak wyjaśnia św. Tomasz - nie posiadając możności-materii, posiadają możność, będącą konsekwencją złożenia $\mathrm{z}$ istoty $\mathrm{i}$ istnienia. W swej Sumie teologicznej ujmuje to w sposób następujący: „Nawet gdy się oderwie materię i przyjmie, że sama forma istnieje - nie w materii - zostaje nadal stosunek formy do samego ist-

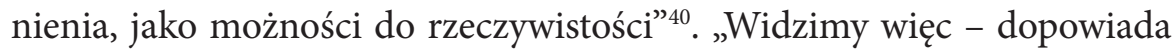
w De substantis separatis - na czym polega różnica między możnością w substancjach duchowych, a możnością, jaką jest materia. Albowiem możność substancji duchowej polega wyłącznie na jej przyporządkowaniu do istnienia, możność zaś materii jest przyporządkowana zarówno formie, jak i istnieniu. Jeśli zaś ktoś obie możności nazywa materią, mówi, rzecz jasna, o materii w dwóch różnych znaczeniach" ${ }^{41}$.

\section{PODSUMOWANIE}

Wykład angelologii św. Tomasza z Akwinu stanowi doskonały przykład wykorzystania filozoficznego instrumentarium $\mathrm{w}$ celu racjonalizacji prawd objawionych. W skład tego instrumentarium wchodzi m.in. koncepcja złożeń wewnątrzbytowych, wypracowana na gruncie realistycznej metafizyki. Trudno wyobrazić sobie pogłębioną refleksję teologiczną, dotyczącą sposobu istnienia i natury aniołów, bez odwołania się do pojęć takich, jak materia i forma, akt i możność, czy - wreszcie - istota $\mathrm{i}$ istnienie.

Posłużenie się tymi pojęciami pozwoliło Akwinacie przeciwstawić się dwom niebezpiecznym tendencjom, jakie zaznaczyły się w interpretacji

\footnotetext{
${ }^{40}$ ST I, 50, 2.

${ }^{41}$ De substantis separatis, 8.
} 
ludzko-anielskich odniesień. Pierwsza z nich, sięgająca swoimi korzeniami wierzeń orfickich oraz platońskiej koncepcji człowieka jako istoty „nie z tego świata”, polega na redukcji jego natury do wymiaru duchowego. Prowadzi ona w konsekwencji do różnych form szkodliwego, stanowiącego oczywisty fałsz antropologiczny, angelizmu. Druga $z$ wymienionych tendencji również zmierza do zatarcia granic pomiędzy ludzką i anielską naturą, tyle że czyni to na drodze antropomorfizacji duchów czystych, poprzez przypisanie im posiadania jakiejś formy cielesności.

Odwołanie się do hylemorficznej koncepcji bytu pozwoliło Doktorowi Anielskiemu wskazać istotną różnicę w strukturze bytowej - ludzkiej i anielskiej. W świecie duchów czystych nieobecne jest złożenie z materii i formy, dzięki czemu znajdują się one w bytowej hierarchii wyżej, nie tylko aniżeli człowiek pojęty jako cielesno-duchowe compositum, ale również wyżej niż bytująca w oderwaniu od ciała ludzka dusza, która z natury rzeczy zachowuje swoje przyporządkowanie do materii, której była - i kiedyś znów będzie - organizatorką.

Egzystencjalna koncepcja bytu jako złożonego z istoty oraz istnienia umożliwiła Akwinacie rozwiązanie pozornej aporii, związanej z przekonaniem, że uznanie niematerialności bytu prowadzić musi nieuchronnie do akceptacji jego boskości. Koncepcja ta pozwala bowiem na wytyczenie podwójnej granicy, z których jedna dotyczy hylemorficznego złożenia $\mathrm{w}$ obrębie istoty, druga zaś jej połączenia $\mathrm{z}$ aktualizującym tę istotę do stania się realnym bytem, aktem istnienia. Pierwsza $\mathrm{z}$ granic pozwala odróżnić substancje posiadające ciało od substancji czysto duchowych, druga z kolei - rozróżnić to, co boskie, a więc z natury posiadające istnienie, od tego, co stworzone, a więc istniejące jedynie istnieniem udzielonym.

Streszczenie. Angelologia św. Tomasza z Akwinu stanowi doskonały przykład wykorzystania filozoficznego instrumentarium w celu racjonalizacji treści objawionych. W jego skład wchodzi m.in. koncepcja złożeń wewnątrzbytowych, wypracowana na terenie realistycznej metafizyki.

Arystotelesowski hylemorfizm pozwala wskazać na istotną różnicę, zachodzącą pomiędzy człowiekiem oraz prostymi substancjami duchowymi, nie złożonymi z materii i formy. Dzięki temu rozróżnieniu możliwym staje się uniknięcie zatarcia granicy, którego skutkiem jest, bądź to redukcjonizm w spojrzeniu na naturę ludzką, ograniczający ją do jej wymiaru duchowego, bądź też przypisywanie aniołom posiadania jakiejś rodzaju materialnej postaci. 
Będąca dziełem Akwinaty, egzystencjalna koncepcja bytu pozwala z kolei na rozwiązanie pozornej aporii, do jakiej - zdaniem niektórych myślicieli - prowadzić musiało przypisanie w sposób jednoznaczny aniołom atrybutu niematerialności (które miało - ich zdaniem - oznaczać akceptację wielobóstwa). W myśl tej koncepcji boskość nie wiąże się bowiem - jak byli skłonni twierdzić owi myśliciele - z niematerialnością czystych substancji duchowych (tzn. byciem czystym aktem, w sensie bycia czystą formą bez udziału materii), ale $\mathrm{z}$ byciem czystym aktem $\mathrm{w}$ sensie posiadania pełni istnienia (ipsum esse), które należy do samej istoty bytu, tak że nie ma w nim realnej różnicy pomiędzy istotą a istnieniem.

Słowa kluczowe: aniołowie; materia; forma; akt; możność; istota; istnienie.

Abstract. The metaphysical concept of compositions of intra-being in lecture on angelology of St Thomas Aquinas. St Thomas Aquinas's angeology is a perfect example of use of philosophical instruments for the purposes of rationalisation of contents manifested. It includes, among others, a concept of compositions of intra-being as developed within realistic metaphysics.

The Aristotelian hylomorphism makes it possible to indicate a significant difference between a human being and simple spiritual substances, which are not composed of matter and form. Owing to this differentiation, it becomes possible to avoid blurring of the border, which results in either reductionism in perception of a human nature limiting the human nature to spiritual context or ascribing any type of material form to angels.

The existential context of being developed by St Thomas Aquinas allows, on the other hand, for resolving an apparent incompatibility, which, as some thinkers thought, was to have been a result of ascribing the attribute of immateriality to angels (and which, as they thought, meant acceptance of polytheism). Within the meaning of this concept, deity is not associated with immateriality of pure spiritual substances (i.e. being a pure act in the sense of being a pure form without any share of matter), as the thinkers tended to think, but it is associated with being a pure act in the sense of having full existence (ipsum esse), which belongs to the very essence of being and, thus, there is no real difference between essence and existence.

Keywords: angels; matter; form; act; potency; essence; existence.

\section{BIBLIOGRAFIA}

Arystoteles, Metafizyka, 983 b, tłum. K. Leśniak, Warszawa 1984.

Danielski W., Doktor Kościoła, w: Encyklopedia katolicka, red. R. Łukaszyk, L. Bieńkowski, F. Gryglewicz, Lublin 1989, t. IV, kol. 34-35.

Gilson E., Bóg i ateizm, tłum. M. Kochanowska, P. Murzański, Kraków 1996. 
Gilson E., Byt $i$ istota, tłum. D. Eska, J. Nowak, Warszawa 2006.

Gilson E., Tomizm, tłum. J. Rybałt, Warszawa 1998.

Kurdziałek M., Awicebron, w: Powszechna Encyklopedia Filozofii, red. A. Maryniarczyk, t. I, Lublin 2000.

Legutko R., Sokrates, Poznań 2013.

Markowski M., Doktor, w: Encyklopedia katolicka, red. R. Łukaszyk, L. Bieńkowski, F. Gryglewicz, Lublin 1989, t. IV, kol. 34.

Maryniarczyk A., Zeszyty z metafizyki, t. I, Lublin 1998.

Maryniarczyk A., Zeszyty z metafizyki, t. III, Lublin 1999.

Moskal P., Diakonia prawdy i „ancilla theologiae”, w: Rozum otwarty na wiare, red. A. Maryniarczyk, Lublin 2000, s. 107-112.

Platon, Państwo, 514 a, tłum. W. Witwicki, Warszawa 2003.

Reale G., Historia filozofii starożytnej, tłum. I. Zieliński, t. I, Lublin 1993.

Reale G., Historia filozofii starożytnej, tłum. I. Zieliński, t. I, Lublin 1994.

Stępień A.B., Herbut J., Uniwersalia, w: Leksykon filozofii klasycznej, red. J. Herbut, Lublin 1997, s. 526-527.

Swieżawski S., Centralne zagadnienie tomistycznej nauki o duszy (Commensuratio animae ad hoc corpus), „Przegląd Filozoficzny” 44 (1948) 1-3, s. 131-191.

Swieżawski S., Święty Tomasz na nowo odczytany, Kraków 1983.

Św. Tomasz z Akwinu, Dzieła wybrane, red. J. Salij, Kęty 1999. 